\title{
Bioassay-guided Isolation of a Antinociceptive, Anti-inflammatory and Antipyretic Benzofuran Derivative from Viburnum grandiflorum
}

Ghias Uddin ${ }^{1 *}$, Muhammad Alam ${ }^{1}$, Naveed Muhammad ${ }^{2}$, Bina S Siddiqui ${ }^{3}$ and Anwar Sadat ${ }^{1}$

${ }^{1}$ Institute of Chemical Sciences; Centre for Phytomedicine and Medicinal Organic Chemistry, University of Peshawar, Peshawar, Pakistan

${ }^{2}$ Department of Pharmacy, Abdul Wali Khan University Mardan, Pakistan

${ }^{3}$ H.E.J. Research Institute of Chemistry, International Centre for Chemical and Biological Sciences, University of Karachi, Karachi-75270, Pakistan

\begin{abstract}
In tradition system of medicines the Vibernum grandiflorum is widely practiced as antipyretic in the treatment of malaria and typhoid. The current study was designed for scientific validation of antinociceptive, anti-inflammatory and antipyretic effect of $V$. grandiflorum with reference to its chemical composition. The crude ethanolic extract and isolated compound was tested for its antinociceptive effect using acetic acid and hot plate pain models. The anti-inflammatory potential was investigated through carrageenan induced oedema and antipyretic effect was determined using brewer's yeast induced pyrexia. Beside the isolation of $\beta$-sitosterol, ursolic acid and betulin, a benzofurane derivative, 2-(-4'-hydroxy-3'-methoxy-phenyl)-5-(3"-hydroxy-propyl)-3-hydroxy-methyl-7-hydroxy-2, 3 -dihydrobenzofuran was first time isolated from the roots of $V$. grandiflorum. The crude extract and compound 1 were found to be active in protection of induced writhing $(70.45$ and $82.11 \%)$, inhibition of increase in paw volume ( 71.34 and $54.47 \%)$, and attenuation of pyrexia $(71.78$ and $41.68 \%)$. It is concluded that the significant inhibition of acetic acid induced writhing, protection of carrageenan induced paw oedema and attenuation of induced pyrexia by isolated compound 1 strongly supports the antinociceptive, anti-inflammatory and antipyretic effect of the roots of $V$. grandiflorum. This research work also provides scientific rationale to the folkloric use of $V$. grandiflorum as pain killer and antipyretic.
\end{abstract}

Keywords: Viburnum grandiflorum; Benzofurane derivative; Antinociceptive; Anti-inflammatory; Antipyretic; NMR-spectroscopy

\section{Introduction}

Viburnum, a genus of the family Adoxaceae (formerly Capripoliaceae), consists of more than 230 species, mostly distributed in the temperate or subtropical zones from South America to Southeast Asia and the majority of them are endemic [1]. Six species of the genus Viburnum distributed in various localities of Pakistan [2]. The genus Viburnum is well known in folk medicine for their spasmolytic, sedative and anti-asthmatic properties. Viburnum prunifolium specifically used for menstrual cramps, as anti-abortive agent and for prevention of postpartum bleeding [3]. Viburnum grandifluram is locally used as purgative, abdominal pain [4], diuretic, and antimalarial [5]. It is also used for the wound healing [6], stomachache [5,7], whooping cough and respiratory diseases, toothache, typhoid [8] and analgesic [9]. Recently, we have tested $V$. grandifluram for its various in-vitro pharmacological activities and proved good antifungal, antibacterial and phytotoxic [2]. The present studies was designed to employ bioassy fractionation for the isolation of analgesic, anti-inflammatory and antipyretic agents from the roots extract of $V$. grandifluram.

\section{Materials and Methods}

All the studies were strongly approved by the ethical committee of University of Peshawar, Peshawar, Pakistan (1367/UOPEC/2011).

\section{Plant material}

V. grandiflorum roots were collected from Tandyani district Hazara, Khyber Pakhtunkhwa, Pakistan in the month of July 2009. Plant was identified by an eminent taxonomist of Botany Department of Hazara University and a specimen voucher was deposited in the University Herbarium.

\section{Chemicals}

All the solvents used were of chromatographic analytical grade, paracetamol (purity $>99 \%$ ) was donated by Global Pharmaceuticals (Pvt) Ltd., diclofenac sodium (Purity $>99 \%$ ) was donated by Madicraft Pharma (Pvt) Ltd., tramadol, acetic acid, normal saline, Brewer's yeast, carrageenan were purchased from E. Mark (Pvt). Ltd.

\section{Animals}

NMRI mice and Wistar rats of either sex were used for all experiments. Animals were maintained under standard laboratory conditions $\left(12 / 12 \mathrm{~h}\right.$ day night light and dark, $22 \pm 3^{\circ} \mathrm{C}$. Standard food was supplied and fresh water were ad labitum.

\section{General experimental procedures}

Flash column chromatography: silica gel 60 (Merck, 0.063-0.200 $\mathrm{mm})$. Prep TLC: glass plates precoated with silica gel $60 \mathrm{GF}_{254}(0.5 \mathrm{~mm}$ thickness, Merck); detection with I spray. Optical rotations: JASCODIP-360 digital polarimeter. UV: SECOMAN spectrophotometer ANTHJRPC Version 4.1h. 1-D and 2-D NMR: Bruker Avance 600 spectrometer $(600 \mathrm{MHz})$; EI-MS: Varian MAT 312 mass spectrometer. EI source at $250^{\circ} \mathrm{C}$ and $70 \mathrm{eV} ; \mathrm{m} / z$ (rel.\%). The HREIMS spectrum was recorded on Jeol JMS-600H mass spectrometer. CI-MS; Jeol JMS-HX 110. CI carrier gas used was $\mathrm{CH}_{4}$.

*Corresponding author: Ghias Uddin, Institute of Chemical Sciences; Centre for Phytomedicine and Medicinal Organic Chemistry, University of Peshawar, Peshawar, Pakistan, Tel: +923453256686; E-mail: ghiasuddin@upesh.edu.pk; drghiasuddin@hotmail.com

Received October 08, 2013; Accepted November 26, 2013; Published November 28, 2013

Citation: Uddin G, Alam M, Muhammad N, Siddiqui BS, Sadat A (2013) Bioassayguided Isolation of a Antinociceptive, Anti-inflammatory and Antipyretic Benzofuran Derivative from Viburnum grandiflorum. Pharmaceut Anal Acta 4: 274. doi: 10.4172/2153-2435.1000274

Copyright: (c) 2013 Uddin G, et al. This is an open-access article distributed under the terms of the Creative Commons Attribution License, which permits unrestricted use, distribution, and reproduction in any medium, provided the original author and source are credited. 
Citation: Uddin G, Alam M, Muhammad N, Siddiqui BS, Sadat A (2013) Bioassay-guided Isolation of a Antinociceptive, Anti-inflammatory and Antipyretic Benzofuran Derivative from Viburnum grandiflorum. Pharmaceut Anal Acta 4: 274. doi: 10.4172/2153-2435.1000274

Page 2 of 5

\section{Isolation of constituents}

Shade dried roots of $V$. grandiflorum $(14.5 \mathrm{Kg})$ were repeatedly extracted with ethanol $(\mathrm{x} 3)$ at room temperature. Solvent was removed under vacuum to obtain brownish gummy residue (VGCE; $568.4 \mathrm{~g}$ ) which was treated with $n$-hexane to yield $n$-hexane soluble $(15.4 \mathrm{~g})$ and insoluble fractions. The $n$-hexane insoluble fraction was further treated with chloroform to get chloroform soluble (125 g) and insoluble fractions. The latter was again treated with ethyl acetate to yield ethyl acetate soluble and insoluble fractions. The ethyl acetate soluble solvent freed fraction ( $30 \mathrm{~g}$ ) was subjected to gravity CC ( $n$-hexane, $n$-hexaneEtOAc and EtOAc in increasing order of polarity). As a result; 256 fractions were obtained and compiled on the basis of TLC proflie to afford 21 sub-fractions. The fraction $1(0.5 \mathrm{~g})$ was subjected to CC and subsequently to precoated TLC resulted a pure compound $1(12.5 \mathrm{mg})$ along with $\beta$-sitosterol, ursolic acid and betulin compounds. The crude ethanolic extract (VGCE) and isolated compound 1 were evaluated for their antinociceptive, anti-inflammatory and antipyretic effects.

\section{Acute toxicity}

The acute toxicity test [10] was carried out for VGCE to evaluate any possible toxicity. NMRI mice $(n=6)$ of either sex were treated with different doses (500, 1000 and $2000 \mathrm{mg} / \mathrm{kg}$, p.o.), while the control group received saline $(10 \mathrm{ml} / \mathrm{kg})$. All the groups were observed for any gross effect for first $4 \mathrm{~h}$ and then mortality was observed after $24 \mathrm{~h}$.

\section{Analgesic activity}

Acetic acid induced writhing test: All the animals (18-22 g) of either sex were withdrawn from food $2 \mathrm{~h}$ before the start of experiment and divided in various groups. Group I was injected with normal saline $(10 \mathrm{ml} / \mathrm{kg})$ as control, Group II received standard drug diclofenac sodium $(10 \mathrm{mg} / \mathrm{kg})$ while the remaining groups were administer the $\operatorname{VGCE}(50,100$ and $150 \mathrm{mg} / \mathrm{kg}$ ) and compound 1 (5 and $10 \mathrm{mg} / \mathrm{kg}$ ). After $30 \mathrm{~min}$ of above administration, the animals were treated i.p. with $1 \%$ acetic acid, for induction of writhing. The number of abdominal constrictions (writhes) were counted after $5 \mathrm{~min}$ of acetic acid injection for the period of 10 minutes [10].

Hot plat test: Mice of either sex $(n=6)$ weighing $18-22 \mathrm{~g}$ were acclimatized to laboratory conditions one hour before the start of experiment with food and water ad libitum. Animals were then subjected to pre-testing on hot plate (Havard apparatus) maintained at $55 \pm 0.1^{\circ} \mathrm{C}$. Animals having latency time greater than 15 seconds on hot plate during pre-testing were rejected (latency time) [11]. All the animals were divided in various groups each of six mice. Group I was treated with saline $(10 \mathrm{ml} / \mathrm{kg})$, group II was treated with tramadol (30 mg/kg i.p) and rest of the groups were treated with VGCE $(50,100$ and $150 \mathrm{mg} / \mathrm{kg}$ ) and compound 1 (5 and $10 \mathrm{mg} / \mathrm{kg}$, i.p). After $30 \mathrm{~min}$, the animals were placed on hot plate and the latency time (time for which mouse remains on the hot plate $\left(55 \pm 0.1^{\circ} \mathrm{C}\right)$ without licking or flicking of hind limb or jumping) was measured in seconds. In order to prevent the tissue damage a cut-off time of 30 seconds were imposed for all animals. To find out the opiodergic mechanism in the analgesic activity of VGCE and $\mathbf{1}$, a number of groups were treated with naloxone ( $0.5 \mathrm{mg} / \mathrm{kg} \mathrm{s.c.),} \mathrm{VGCE} \mathrm{(100} \mathrm{and} 150 \mathrm{mg} / \mathrm{kg}$, i.p) and 1 (5 and $10 \mathrm{mg})$. After $10 \mathrm{~min}$, these groups were treated with tramadol $(30 \mathrm{mg} / \mathrm{kg}$ i.p.) and naloxone injection. The latency time for all groups was recorded at $0,30,60,90$ and $120 \mathrm{~min}$. Percent analgesia was calculated using the following formula:

$\%$ Analgesia $=($ Test latency-control latency $) /($ Cut-off time-control latency) $\times 100$

\section{Anti-inflammatory activity}

The anti-inflammatory activity was performed on Wister rats of either sex (150-290 g). The animals were randomly divided in various groups each of six animals [12]. Group I was treated with normal saline $(10 \mathrm{ml} / \mathrm{kg})$ while group II with diclofenac sodium $(10 \mathrm{mg} / \mathrm{kg})$ and rest of the groups were treated with $\operatorname{VGCE}(50,100$ and $150 \mathrm{mg} / \mathrm{kg}$, i.p) and $1(5$ and $10 \mathrm{mg} / \mathrm{kg})$. After thirty minutes of the above intraperitoneal administration, carrageenan $(1 \%, 0.05 \mathrm{ml})$ was injected subcutaneously in the sub- plantar tissue of the right hind paw of each rat. The inflammation was measured using plethysmometer (LE 7500 plan lab S.L) immediately after injection of carrageenan and then 1,2,3,4 and $5 \mathrm{~h}$. The average foot swelling in drug treated animal as well as standard was compared with control and the percent inhibition (anti-inflammatory activity) of edema was determined using the formula.

Percent inhibition $=\mathrm{A}-\mathrm{B} / \mathrm{A} \times 100$, where $\mathrm{A}$ represent edema volume of control and $B$ as paw edema of tested group.

\section{Antipyretic test}

The antipyretic activity was evaluated for $\operatorname{VGCE}(50,100$ and 150 $\mathrm{mg} / \mathrm{kg}$ ) and 1 ( 5 and $10 \mathrm{mg} / \mathrm{kg}$ ) using mice (25-30 g) of either sex. The selected animals were healthy and were acclimatized to laboratory conditions before the start of experiment. The animals were divided into various groups each of six rats. The normal body temperature of each rat was recorded using digital thermometer and then pyrexia was induced by injecting $20 \%$ aqueous suspension of brewer's yeast $(10 \mathrm{ml} / \mathrm{kg} \mathrm{s.c.}$.). All groups were fasted overnight but allowed free accesses to drinking water and after $24 \mathrm{~h}$ rectal temperature of each mouse was recorded. The induction of pyrexia was confirmed by rise in temperature more than $0.5^{\circ} \mathrm{C}$, while animals showed rise in temperature less than $0.5^{\circ} \mathrm{C}$ were excluded from experiment [13]. Group I received saline $(10 \mathrm{ml} /$ $\mathrm{kg})$ as a negative control and group II received paracetamol $(150 \mathrm{mg} /$ $\mathrm{kg}$ ) as a standard drug while the remaining groups were treated with $\operatorname{VGCE}(50,100$ and $150 \mathrm{mg} / \mathrm{kg}$ ) and 1 (5 and $10 \mathrm{mg} / \mathrm{kg})$. After drugs administration, rectal temperature was again recorded periodically at 1 , $2,3,4$ and $5 \mathrm{~h}$ of drugs administration. The percent reduction in pyrexia was calculated by the following formula.

\section{Percent reduction $=(\mathrm{Ta}-\mathrm{Tb}) / \mathrm{Tb} \times 100$}

Where, Ta represents normal body temperature; $\mathrm{Tb}$ temperature after yeast injection

\section{Statistical analysis}

The results obtained were expressed as mean \pm SEM (Standard error of mean) of six animals. For statistical analysis, ANOVA was followed by post hoc Dunnett's test for multiple comparisons. Effects were considered to be significant at the $\mathrm{P}<0.05$ level.

\section{Results}

\section{Identification of isolated compound}

The purification of the ethanollic curde extract of $V$. grandiflorum roots (VGCE) afforded hitherto unreported benzofuran derivative 1 as brownish amorphous powder together with $\beta$-sitosterol, ursolic acid and betulin. The IR spectrum exhibited major absorption bands at 3340 and $1610-1415 \mathrm{~cm}^{-1}$ indicating the presence of hydroxyl group and aromatic carbon-carbon double bond, respectively. The molecular ion peak was observed at $m / z 346$ in the EI-MS of compound 1 and its molecular formula was assigned $\mathrm{C}_{19} \mathrm{H}_{22} \mathrm{O}_{6}$ by HREI-MS which gave 
Citation: Uddin G, Alam M, Muhammad N, Siddiqui BS, Sadat A (2013) Bioassay-guided Isolation of a Antinociceptive, Anti-inflammatory and Antipyretic Benzofuran Derivative from Viburnum grandiflorum. Pharmaceut Anal Acta 4: 274. doi: 10.4172/2153-2435.1000274

Page 3 of 5

exact molecular mass as $m / z$ 346.1464. The proton NMR spectrum (Table 1) of compound 1 showed the characteristics signals of five aromatic methines at $\delta \mathrm{H} 6.96\left({ }^{1} \mathrm{H}, \mathrm{s}\right), 6.83(1 \mathrm{H}, \mathrm{d}, J 7.2), 6.76\left({ }^{1} \mathrm{H}, \mathrm{d}, \mathrm{J}\right.$ 7.8), $6.59\left({ }^{1} \mathrm{H}, \mathrm{s}\right)$, and $6.55\left({ }^{1} \mathrm{H}, \mathrm{s}\right)$ indicating two substituted aromatic rings. These signals were assigned to H-2, H-6, H-5, H-4 and H-6 and the ${ }^{13} \mathrm{C}$ signals at $\delta_{\mathrm{C}} 110.3\left(\mathrm{C}-2^{\prime}\right), 119.6\left(\mathrm{C}-6^{\prime}\right), 116.0\left(\mathrm{C}-5^{\prime}\right), 116.6$ (C- 4), and 116.9 (C- 6) respectively by HMQC analyses. The proton NMR spectrum further showed an $\mathrm{O}$-methines and a methines at $\delta_{\mathrm{H}} 5.48\left({ }^{1} \mathrm{H} \mathrm{d}, J 6.0, \mathrm{H}-2\right)$ and $3.43\left({ }^{1} \mathrm{H}, \mathrm{t}, J 6.6, \mathrm{H}-3\right)$. These signals showed connectivities with $\mathrm{C}-2$ and $\mathrm{C}-3$ at $\delta_{\mathrm{C}} 88.6$ and 55.7 respectively, suggesting a substituted benzofuran derivative. A hydroxy methylene signal was also observed at $\delta_{\mathrm{H}} 3.73\left({ }^{2} \mathrm{H}, \mathrm{dd}, \mathrm{J} 10.8,7.8\right), \delta_{\mathrm{C}} 65.0(\mathrm{C}-$ 1 '”). The observed correlation in HMBC (Table 1) between the methoxy protons at $\delta_{\mathrm{H}} 3.80$ and the ${ }^{13} \mathrm{C}$ signal at $\delta_{\mathrm{C}} 149.0$, which showed cross peak with the ${ }^{1} \mathrm{H}$ signal at $\delta_{\mathrm{H}} 6.96\left(\mathrm{H}-2,{ }^{2} \mathrm{~J}\right)$, indicated that the methoxy group must be vicinal to C-2'. Two aromatic hydroxy groups were confirmed by the observed correlations between the ${ }^{1} \mathrm{H}$ signal of $\mathrm{H}-6$ ' at $\delta_{\mathrm{H}} 6.83$ and the ${ }^{13} \mathrm{C}$ signals of C-2' $\left(\delta_{\mathrm{C}} 110.3\right), \mathrm{C}-4^{\prime}\left(\delta_{\mathrm{C}} 147.3\right)$ and $\mathrm{C}-5^{\prime}\left(\delta_{\mathrm{C}} 116\right)$, which indicated that one hydroxyl group to be located at C-4. Similarly, ${ }^{1} \mathrm{H}$ signal of $\mathrm{H}-6$ at $\delta_{\mathrm{H}} 6.55$ and the ${ }^{13} \mathrm{C}$ signals of $\mathrm{C}-4\left(\delta_{\mathrm{C}} 116.6\right), \mathrm{C}-6$ $\left(\delta_{\mathrm{C}} 116.9\right)$ and $\mathrm{C}-7\left(\delta_{\mathrm{C}} 146.4\right)$ suggested that another hydroxyl group to be located at C-7. Moreover, the existence of a correlation between the ${ }^{1} \mathrm{H}$ signals at $\delta_{\mathrm{H}} 6.59(\mathrm{H}-4)$ and $6.55(\mathrm{H}-6)$ with the ${ }^{13} \mathrm{C}$ signal at $\delta \mathrm{C} 32.7$ suggested a methylene substituent at $\mathrm{C}-5$. This methylene substituent indicated the presence of a structural unit, $-\mathrm{CH}_{2}-\mathrm{CH}_{2}-$ $\mathrm{CH}_{2}-\mathrm{OH}$ at C-5 $\left(\delta_{\mathrm{H}} 2.55, \mathrm{t}, J 7.2 \mathrm{~Hz}, \delta_{\mathrm{C}} 32.7, \mathrm{C}-1\right.$ "; $\delta_{\mathrm{H}} 1.78, \mathrm{~m}, \delta_{\mathrm{C}} 35.5$, $\mathrm{C}-2$ "; $\delta_{\mathrm{H}} 3.54, \mathrm{t}, J 6.6 \mathrm{~Hz}, \delta_{\mathrm{C}} 62.2, \mathrm{C}-3$ "). This substitution pattern was further supported by the $\mathrm{HMBC}$ correlation between $\mathrm{H}-4$ and $\mathrm{H}-6$ with C-1". The substitution of $-\mathrm{CH} 2 \mathrm{OH}$ was also confirmed by the HMBC correlation at C-3 between H-1"' with C-2 and C-3 (Figure 1). The substitution pattern and structure of 1 was further confirmed with the help of NOESY and ${ }^{1} \mathrm{H}-{ }^{1} \mathrm{H}$ COSY correlations (Figure 1). Thus, on the basis of these facts the structure of 1 was elucidated as cedrusin [14] (2(-4'-hydroxy-3'-methoxy-phenyl)-5-(3"'-hydroxy-propyl)-3-hydroxymethyl -7-hydroxy-2, 3-dihydrobenzofuran) hitherto unreported from V. grandiflorum. The detailed 1D and 2D NMR spectroscopy study of 1 was also reported first time.

\begin{tabular}{|c|c|c|c|}
\hline Position & $\delta{ }^{13} \mathbf{C}$, mult & $\delta^{1} \mathbf{H}, \mathbf{m}, \mathbf{J}(\mathbf{H z})$ & HMBC $\left({ }^{1} \mathrm{H}-{ }^{13} \mathrm{C}\right)$ \\
\hline 2 & $88.6, \mathrm{CH}$ & $5.48, \mathrm{~d}, 6$ & $3,1 " ', 2 ', 3 a, 1 ', 7 a$ \\
\hline 3 & $55.7, \mathrm{CH}$ & $3.43, t, 6.6$ & 1"', 3a, 1', 2 \\
\hline $3 a$ & 129.7, C & - & \\
\hline 4 & 116.6, $\mathrm{CH}$ & $6.59, \mathrm{~s}$ & $1 ", 3,6,7 a$ \\
\hline 5 & 136.7, C & - & \\
\hline 6 & 116.9, $\mathrm{CH}$ & $6.55, \mathrm{~s}$ & $1 ", 4,7,7 a$ \\
\hline 7 & $141.8, \mathrm{C}$ & - & \\
\hline $7 a$ & 146.4, C & - & \\
\hline $1^{\prime}$ & $135, C$ & - & \\
\hline $2^{\prime}$ & $110.3, \mathrm{CH}$ & $6.96, \mathrm{~s}$ & $2,3^{\prime}, 4^{\prime}, 6^{\prime}$ \\
\hline $3^{\prime}$ & $149, \mathrm{C}$ & - & \\
\hline $4^{\prime}$ & 147.3, C & - & \\
\hline $5^{\prime}$ & $116, \mathrm{CH}$ & $6.76, d, 7.8$ & $1^{\prime}, 4^{\prime}, 6^{\prime}$ \\
\hline $6^{\prime}$ & 119.6, CH & $6.83, \mathrm{~d}, 7.2$ & $2,2^{\prime} 4^{\prime}$ \\
\hline 1" & $32.7, \mathrm{CH} 2$ & $2.55, \mathrm{t}, 7.2$ & 2", 3", 5, 4 \\
\hline 2" & $35.5, \mathrm{CH} 2$ & $1.78, t, 7.2$ & 1", 3", 5 \\
\hline 3" & $62.2, \mathrm{CH} 2$ & $3.54, t, 6.6$ & 1", 2" \\
\hline 1" & $65, \mathrm{CH} 2$ & $3.73, \mathrm{t}, 7.8$ & $2,3,3 a$ \\
\hline $\mathrm{OCH} 3$ & $56.2, \mathrm{CH} 3$ & $3.8, s$ & $3^{\prime}$ \\
\hline
\end{tabular}

\section{Antinociceptive effect}

VGCE and compound 1 were scrutinized for their antinociceptive potentials using chemical and thermal induced pain paradigm. The antinociceptive results (Table 2) revealed VGCE $(150 \mathrm{mg} / \mathrm{kg})$ and compound $1(10 \mathrm{mg} / \mathrm{kg})$ were found to be active in attenuating $(70.45$ and $82.11 \%)$ the acetic acid induced writhing in mice. In comparison with the analgesic effect $(87.23 \%)$ of diclofenac sodium $(10 \mathrm{mg} /$ $\mathrm{kg}$ ) the effect of VGCE was somewhat lesser while $\mathbf{1}$ was dominant antinociceptive. In addition to the pain protected in acetic acid induce experiment both of the tested samples were failed (data not presented) to increase the latency time of mice in hot plate pain model.

\section{Anti-inflammatory effect}

The anti-inflammatory effect of VGCE (50,100 and $150 \mathrm{mg} / \mathrm{kg})$ and 1 (5 and $10 \mathrm{mg} / \mathrm{kg}$ ) is presented in Figure 2 and Figure 3, respectively. A dose dependant protection of paw edema was noticed with both tested samples. VGCE $(150 \mathrm{mg} / \mathrm{kg})$ showed anti-inflammatory effect at first (\% protection, $60.33,1^{\text {st }} \mathrm{h}$ ) and second stage (\% protection, $71.34,4^{\text {th }}$ h) of inflammation, while the anti-inflammatory potential of $1(10 \mathrm{mg} /$ $\mathrm{kg}$ ) was weaker than at both stages (\% protection, $41.45,1^{\text {st }} \mathrm{h}$ and 54.47 at $4^{\text {th }} \mathrm{h}$ ). Diclofenac sodium exhibited very strong effect as compared to both tested samples.

\section{Antipyretic effect}

The maximum antipyretic effect $(71.78 \%)$ was exhibited by VGCE $\left(150 \mathrm{mg} / \mathrm{kg}\right.$ ) at the $3^{\text {rd }} \mathrm{h}$ of post treatment (Figure 4$)$, while the pyrexia reducing potential of $1(10 \mathrm{mg} / \mathrm{kg}$ ) at the same time was $41.68 \%$ (Figure $5)$. Both of tested samples demonstrated attenuation of temperature

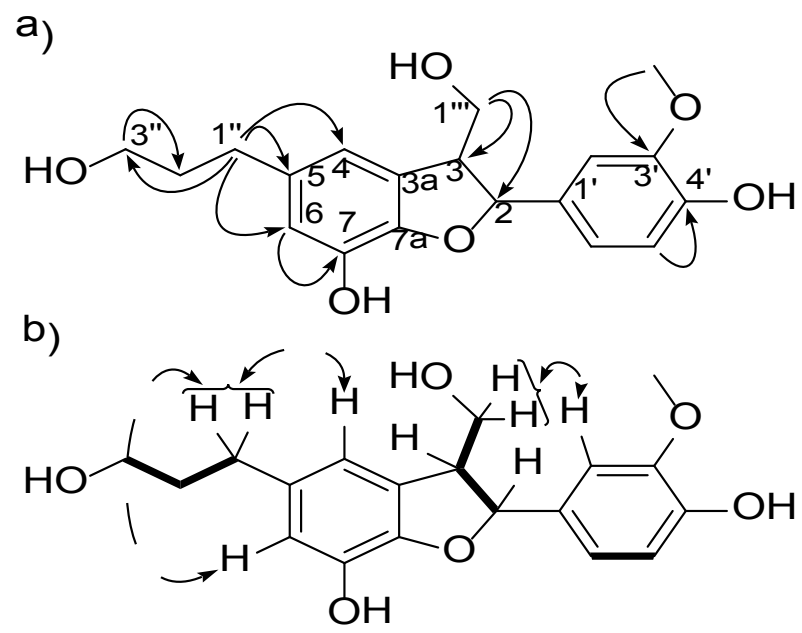

Figure 1: a) Important HMBC ( $\curvearrowright$ ) correlations, b) $1 \mathrm{H}-1 \mathrm{H} \mathrm{COSY}(-)$ correlations and NOESY $(\cdots)$ correlations observed for compound (1).

\begin{tabular}{|l|c|c|}
\hline Sample & Dose $(\mathbf{m g} / \mathbf{k g})$ & Percent analgesia \\
\hline Normal saline & $10 \mathrm{mg} / \mathrm{kg}$ & - \\
\hline $\begin{array}{l}\text { Diclofenac } \\
\text { sodium }\end{array}$ & 10 & $87.23 \pm 0.44^{* * *}$ \\
\hline VGCE & 50 & $23.26 \pm 1.43^{*}$ \\
\cline { 2 - 3 } & 100 & $40.99 \pm 2.98^{*}$ \\
\hline \multirow{2}{*}{1} & 150 & $72.09 \pm 2.11^{* *}$ \\
\hline & 5 & $70.45 \pm 2.98^{* *}$ \\
\hline
\end{tabular}

Table 2: Antinociceptive activities of VGCE and 1 as determined by the acetic acid induced writhing test in mice. 
Citation: Uddin G, Alam M, Muhammad N, Siddiqui BS, Sadat A (2013) Bioassay-guided Isolation of a Antinociceptive, Anti-inflammatory and Antipyretic Benzofuran Derivative from Viburnum grandiflorum. Pharmaceut Anal Acta 4: 274. doi: 10.4172/2153-2435.1000274

Page 4 of 5

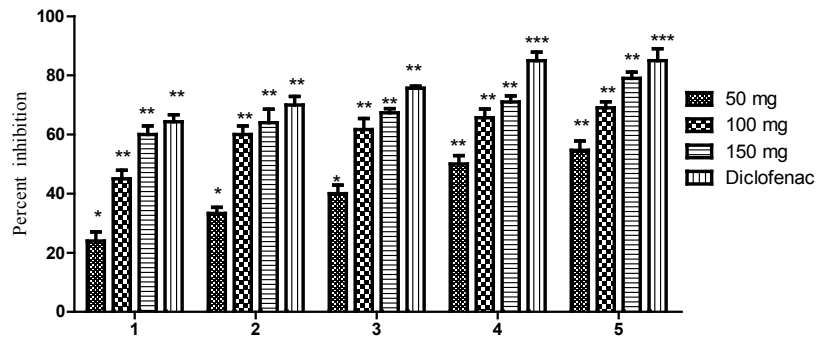

Figure 2: Anti-inflammatory effect of VGCE against carrageenan paw oedema in NMRI mice.

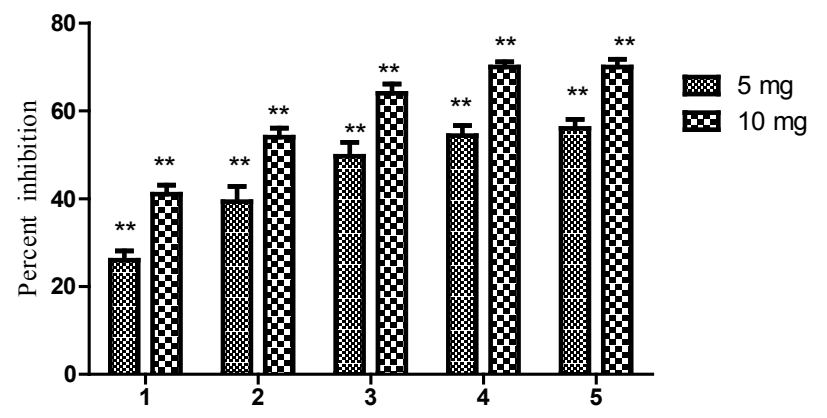

Figure 3: Anti-inflammatory effect of 1 against carrageenan paw oedema in NMRI mice.

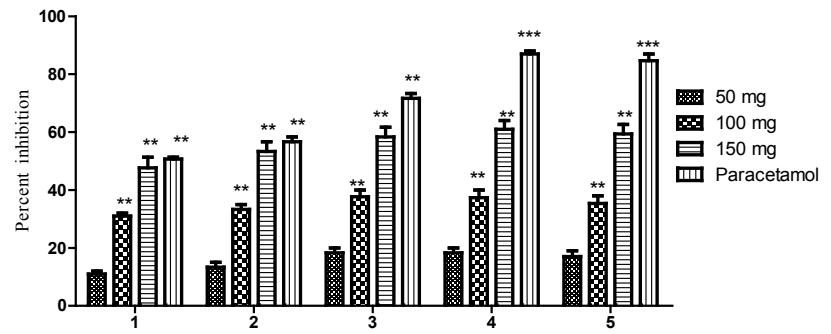

Figure 4: Antipyretic effect of VGCE against brewer's yeast induced pyrexia in NMRI mice.

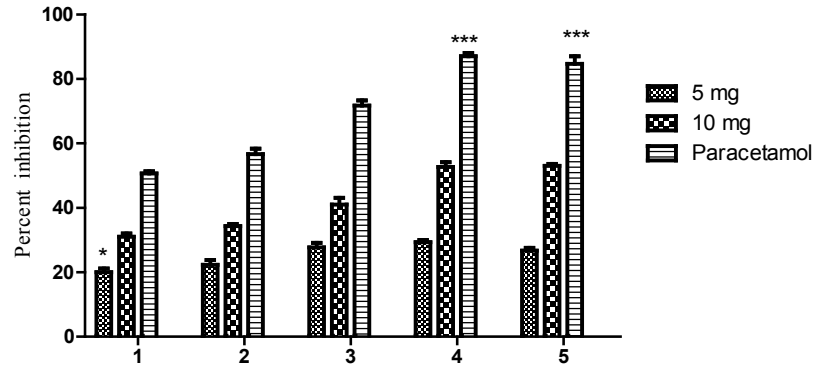

Figure 5: Antipyretic effect of 1 against brewer's yeast induced pyrexia in NMRI mice.

in fibril mice from the $1^{\text {st }} \mathrm{h}$ of post treatment which was maintained throughout the experiment. The fever reducing effect of paracetamol was higher than both of the samples.

\section{Discussion}

The crude ethanolic extract of the roots and isolated compound was tested for their antinociceptive, anti-inflammatory, and antipyretic effects. The chemical induced pain paradigm (acetic acid) is one of well established procedure for exploring the medicinal plants or any substance for its peripheral antinociceptive potential [15]. The thermal pain model is mostly practiced for finding the central antinociceptive effect of the tested substances [16]. The reduction of acetic acid induced writhing in mice by compound 1 and the failure of 1 in increasing the latency time of mice clearly explain the that VGCE has peripheral antinociceptive effect due to the presence of 1 . Carrageenan induced paw edema is one of the simple and well reported method of testing substances for its anti-inflammatory effect. The first phase of inflammation is mostly attributed to release of histamine while the etiology of the second phase of inflammation is the release of prostaglandins $[15,17]$ which notorious for induction of inflammation. The crude extract of the roots (VGCE) as well as its isolated compound 1 demonstrated parallel anti-inflammatory results i.e. the protection of induced oedema was weak in the first phase of inflammation as compared to the second phase. Regarding the antipyretic effect of the crude and isolated compound, both significantly attenuated the pyrexia of fibril mice dose dependently which is clearly indicated that antinociceptive, anti-inflammatory and antipyretic effect of the crude extract is strongly attributed to the presence of $\mathbf{1}$. The present research work strongly supports the ethnomedicinal uses of this plant as antipyretic and analgesic. Further the isolated compound 1 would constitute a useful model for the development of a new class of plant based analgesic, anti-inflammatory and antipyretic agents that would be entitled to further investigation and derivatization reducing the adverse effect of NSAIDs class of drugs.

\section{Conclusion}

The roots of $V$. grandifluram can be used safely in the treatment of pain, inflammation, and pyrexia. The presence of $1, \beta$-sitosterol, ursolic acid and betulin further strengthens the uses of this plant in aforementioned ailments.

\section{Acknowledgments}

Authors are thankful to Higher Education Commission (HEC) of Pakistan for providing financial support and H.E.J. Research Institute of Chemistry, International Centre for Chemical and Biological Sciences, University of Karachi, Karachi, Pakistan for providing research facilities.

\section{References}

1. Lobstein A, Haan-Archipoff G, Englert J, Kuhry JG , Anton R (1999) Chemotaxonomical investigation in the genus Viburnum. Phytochemistry 50 1175-1180.

2. Alam M, Ghiasuddin, Sadat A, Muhammd N, Khan AA, Siddiqui SB (2012) Evaluation of Viburnum grandiflorum for its in-vitro pharmacological screening. African Journal of Pharmacy and Pharmacology 6: 1606-1610.

3. Wang E , Li G (2009) A review on the studies of Viburnum genus. Journal of Jiangsu Forestry Science \& Technology 1: 50-54.

4. Kumar M, Paul Y, Anand V (2009) An ethnobotanical study of medicinal plants used by the locals in Kishtwar, Jammu and Kashmir, India, Ethnobotanical Leaflets 13:1240-1256.

5. Dar M (2003) Ethnobotonical uses of plants of Lawat district Muzaffarabad Azad Jammu and Kashmir. Asian J Plant Sci 2: 680-682.

6. Nautiyal S, Maikhuri R, Rao K, Saxena K (2001) Medicinal plant resources in Nanda Devi Biosphere Reserve in the central Himalayas. Journal of herbs, spices \& medicinal plants 8: 47-64

7. Latif A, Shinwari Z,. Hussain J, Murtaza S (2006) NTFPS: An alternative to forest logging in Minadam and Sultanar Valley Swat. Lyonia 11: 15-21. 
Citation: Uddin G, Alam M, Muhammad N, Siddiqui BS, Sadat A (2013) Bioassay-guided Isolation of a Antinociceptive, Anti-inflammatory and Antipyretic Benzofuran Derivative from Viburnum grandiflorum. Pharmaceut Anal Acta 4: 274. doi: 10.4172/2153-2435.1000274

Page 5 of 5

8. Khan Z, Khuroo A, Dar G (2004) Ethnomedicinal survey of Uri, Kashmir Himalaya. Ind J Trad Know 3: 351-357.

9. Balangcod TD, AKD B (2011) Ethnomedicinal knowledge of plants and health care practice among the kalaguyo tribes in Tinoc, Ifugeo, Luzon and Phillipine. Indian Journal of Trraditional Kwonledage 10: 227 - 238.

10. Khan H, Saeed M, Gilani AU, Khan MA, Dar A, et al. (2010) The antinociceptive activity of Polygonatum verticillatum rhizomes in pain models. J Ethnopharmacol 127: 521-527.

11. Brochet D, Micó JA, Martin P, Simon P (1986) Antinociceptive activity of betaadrenoceptor agonists in the hot plate test in mice. Psychopharmacology (Berl) 88: $527-528$

12. Khan I, Nisar M, Ebad F, Nadeem S, Saeed M, et al. (2009) Anti-inflammatory activities of Sieboldogenin from Smilax china Linn.: experimental and computational studies. J Ethnopharmacol 121: 175-177.
13. Kang JY, Khan MN, Park NH, Cho JY, Lee MC, et al. (2008) Antipyretic analgesic, and anti-inflammatory activities of the seaweed Sargassum fulvellum and Sargassum thunbergii in mice. J Ethnopharmacol 116: 187-190.

14. Yang SP, Wang Y, Wu Y, Yue JM (2004) Chemical constituents from Pseudolarix kaempferi. Nat Prod Res 18: 439-446.

15. Muhammad N, Saeed M, Khan H (2012) Antipyretic, analgesic and antiinflammatory activity of Viola betonicifolia whole plant. BMC Complement Altern Med 12: 59

16. Khan MA, Khan $H$, Khan S, Mahmood T, Khan PM, et al. (2009) Antiinflammatory, analgesic and antipyretic activities of Physalis minima Linn. J Enzyme Inhib Med Chem 24: 632-637.

17. Khan H, Khan MA, Muhammad N, Ashraf A, Gul F, et al. (2012) Antiinflammatory and antioxidant activity of Joshanda partially mediated through inhibition of lipoxygenase. Phytopharmacology 3: 19-28. 